\title{
Evaluation of formulation and effects of process parameters on drug release and mechanical properties of tramadol hydrochloride sustained release matrix tablets
}

\author{
Nenad D. Nikolić ${ }^{1}$, Djordje P. Medarević ${ }^{2}$, Svetlana R. Ibrić ${ }^{2}$, Zorica R. Djurić ${ }^{2}$ \\ ${ }^{1}$ Hemofarm a.d., Beogradski drum b.b., Vršac, Serbia \\ ${ }^{2}$ Faculty of Pharmacy, Department of Pharmaceutical Technology, University of Belgrade, Belgrade, Serbia
}

\begin{abstract}
This study investigates the use of high molecular weight polyethylene oxide (PEO WSR coagulant) for the preparation of sustained release matrix tablets containing high dose, highly water soluble drug, tramadol $\mathrm{HCl}$. Proportion of PEO polymer, type of insoluble filler, proportion of tramadol $\mathrm{HCl}$, amount of drug in tablet, tablet diameter and compression pressure were recognized as critical formulation and process parameters and their influence on drug release and tablet mechanical properties was evaluated. Percentages of tramadol $\mathrm{HCl}$ released after 30 and 240 min were selected for evaluation of drug release, while tensile strength was used as indicator of tablet mechanical properties. Only proportion of tramadol $\mathrm{HCl}$ exhibits statistically significant effect on percentages of tramadol $\mathrm{HCl}$ released after 30 and $240 \mathrm{~min}$, with higher, wherein increasing of the tramadol $\mathrm{HCl}$ proportion increased its release rate among the evaluated variables in selected ranges. All of the investigated factors exhibit statistically significant effect on tablets tensile strength, with the largest influence of filler type. Tablets prepared with highly compressible filler (microcrystalline cellulose) exhibit higher tensile strength and therefore better mechanical properties to those prepared with partially pregelatinized starch (starch 1500).
\end{abstract}

Keywords: tramadol $\mathrm{HCl}$, matrix tablets, PEO WSR coagulant, drug release, mechanical properties of tablets.

SCIENTIFIC PAPER

UDC 615:661.12:66

Hem. Ind. 69 (5) 503-510 (2015)

doi: 10.2298/HEMIND140317069N

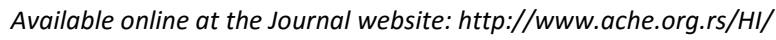

The usage of hydrophilic polymers, as the release rate control agents in matrix sustained release formulations, has been considered as the simplest and most cost-effective method for preparation of extended release solid dosage forms [1]. Numerous types of synthetic and natural polymers have been established for formulating hydrophilic matrix tablets, such as hypromellose, polyethylene oxide, hydroxypropylcellulose, etc. [2]. Polyethylene oxides (PEOs) are class of hydrophilic nonionic linear polymers, commercially available in variable grades, with average molecular weight in range from 100000 to 8000000 . They were introduced as alternative to cellulose derivatives, the most commonly used polymers in the formulation of extended release matrix tablets $[3,4]$. There are several important features of PEO polymers that favor their wide application in the formulation of hydrophilic extended release matrix tablets, such as their physical and chemical stability, non-toxicity, insensitivity to the $\mathrm{pH}$ of the physiological fluids, good compressibility and high swelling ability [5]. In the previous studies, the high

Correspondence: S.R. Ibrić, Faculty of Pharmacy, Department of Pharmaceutical Technology, Vojvode Stepe 450, 11221 Belgrade, Serbia.

E-mail: svetlana.ibric@pharmacy.bg.ac.rs

Paper received: 17 March, 2014

Paper accepted: 22 September, 2014 molecular weight PEOs have been successfully used in the preparation of sustained release matrix tablets by direct compression, containing either water soluble or insoluble drug $[6,7]$. Once in contact with water, the PEO matrix starts to swell due to formation of hydrogen bonds between polymeric chains and water. Formation of the hydrophilic gel layer is responsible for prolonged drug release [8]. Basic processes, which determine drug release from hydrophilic matrix tablets, are drug diffusion through the gel layer as well as erosion of the swollen gel layer [9]. Solubility of the drug has profound influence on the mechanism that determined drug release from matrix and should be considered in selecting proper type and grade of matrix polymer. Release of highly water soluble drug from hydrophilic matrix system is mainly controlled by the diffusion through the swollen gel layer, whereas release of poorly soluble drug is dominantly controlled by the polymer erosion (relaxation) [10]. Tablet geometry has also profound influence on the drug release from diffusion-controlled systems and this has been studied in details by Siepmann et al. [11]. Thus, the effect of a tablet surface/tablet volume ratio (SA/Vol) on the drug release from hydrophilic matrices was investigated for hypromellose matrix tablets [12] and for hydroxypropylcellulose matrix tablets [13]. 
In formulation of hydrophilic matrix tablets with high-dose, highly soluble drug, the two important issues, regarding selecting of proper matrix polymer, should be considered: the capability of polymer to prevent premature drug release, as well as ability to sustain drug release with predictable kinetics. Another important characteristic of matrix tablets should be acceptable mechanical properties in order to maintain tablet integrity during further processing, such as packaging and coating and application by the patient. Mechanical properties of powder mixtures and compacts can be assessed through evaluation of compressibility (solid fraction vs. compaction pressure), compactibility (tensile strength vs. solid fraction) and tabletability (tensile strength vs. compaction pressure). Yang et al. have proved that under applied compression pressure the consolidation mechanism of PEO follows plastic deformation. However, characteristic viscoelastic behavior of PEOs with large axial expansion after compression results in production of low tensile strength tablets. According to these results it was suggested that PEO polymers should be used with highly compactible excipients [14]. Comparison of the drug release, as well as mechanical characteristics between hypromellose $100000 \mathrm{mPa}$ s and different high viscosity PEOs (Polyox TM WSR 1105, 301 and 303), was performed on matrix tablets containing metformin $\mathrm{HCl}$ as a model drug. The results of this study proved lower tabletability of PEO in respect to HPMC [15]. Most of the studies that investigate mechanical characteristics of hydrophilic matrix tablets were conducted on either excenter tablet press or instrumented small rotary press. There are numerous advantages of using compaction simulator in comparison to conventional tablet presses. It offers studying of basic compaction mechanisms, evaluation of influence of process variables on tablet properties, determination of scale-up parameters, creating compaction data bank, and fingerprinting of new active pharmaceutical ingredients (APIs) or excipients [16]. Using of compaction simulator enables evaluation and comparison of powder mechanical properties in simulated production conditions. Mathematical equations can be used to describe compaction events and density-pressure relationships that predict the pressures required for achieving an optimum compact density. This understanding has found active application in solving the analytical problems related to tableting, such as capping, lamination, picking, sticking, etc. Mathematical models, such as forcetime, force-distance, and die-wall force parameters are used to describe work of compaction, elasticity, plasticity, and time dependent deformation behavior of pharmaceuticals. Parameters such as the bonding index, brittle fracture index and strain index can be used to predict compaction related problems [16].
This study investigates using of high molecular weight PEO (Polyox WSR coagulant) for the preparation of sustained release matrix tablets with high dose, highly soluble model drug, tramadol $\mathrm{HCl}$. Both drug release and tablets mechanical properties were recognized as critical quality attributes of hydrophilic matrix tablets. Critical formulation (proportion of PEO polymer, type of insoluble filler, proportion of tramadol $\mathrm{HCl}$, amount of drug in tablet and tablet diameter) and process parameters (compression pressure) were selected in the study and the influence of these parameters on drug release and tablet mechanical properties was evaluated. Aim of this study was preliminary evaluation of selected variables on tablet quality attributes, since all variables were varied on two levels through screening experimental design.

\section{EXPERIMENTAL}

\section{Materials}

The following materials were used: polyethylene oxide (Polyox WSR coagulant, Dow Chemical Company, Midland, TX, USA), microcrystalline cellulose (Avicel PH 102, FMC Biopolymer, USA), partially pregelatinized maize starch (Starch 1500, Colorcon, Dartford, Kent, UK), colloidal silicon dioxide (Aerosil 200 Pharma, Degussa), magnesium stearate (Mallinckrodt, St. Louis, MO, USA). Tramadol HCl (Hemofarm A.D., Vršac, Serbia) was used as model of high dose, highly water soluble drug.

\section{Experimental design}

In the first part, the experiments were conducted to evaluate the influence of formulation (proportion of PEO polymer, type of insoluble filler, proportion of tramadol $\mathrm{HCl}$, amount of drug in tablet and tablet diameter) and process parameter (compression pressure) on tramadol release. Percentage of drug release from matrix tablets after 30 and 240 min were selected as response variables. Experiments were performed according to $2^{5-2}$ fractional factorial design, as presented in the Table 1.

In order to eliminate influence of matrix tablets geometry on drug release, normalization of the percentage of drug released after 30 and $240 \mathrm{~min}$, was performed by dividing obtained drug released percentage with surface area per volume ratio $(S A / \mathrm{Vol})$ of tablets.

In the second part of the study $2^{3}$ full factorial design was used to evaluate the influence of the matrix polymer proportion, type of filler and drug proportion on the tablet mechanical properties. Levels of investigated variables are presented in Table 1 . Tensile strength $\left(\sigma_{t}\right)$ was used as an indicator of tablets mechanical properties, enabling comparison of mechanical 
Table 1. Experimental matrix according to $2^{5-2}$ and $2^{3}$ experimental design

\begin{tabular}{|c|c|c|c|c|c|c|}
\hline Formulation & $\begin{array}{c}\text { Proportion of PEO } \\
\text { polymer, } \%\end{array}$ & Filler type ${ }^{a}$ & $\begin{array}{l}\text { Proportion of tramadol } \\
\qquad \mathrm{HCl}, \%\end{array}$ & $\begin{array}{l}\text { Compression } \\
\text { pressure, MPa }\end{array}$ & $\begin{array}{c}\text { Tramadol } \mathrm{HCl} \text { per } \\
\text { tablet, } \mathrm{mg}\end{array}$ & $\begin{array}{c}\text { Tablet } \\
\text { diameter, } \mathrm{mm}\end{array}$ \\
\hline $\mathrm{F} 1$ & 25 & Starch 1500 & 55.6 & 300 & 200 & 10 \\
\hline $\mathrm{F} 2$ & 35 & Starch 1500 & 55.6 & 150 & 100 & 7 \\
\hline F3 & 25 & Avicel PH 102 & 55.6 & 150 & 200 & 13 \\
\hline F4 & 35 & Avicel PH 102 & 55.6 & 300 & 100 & 7 \\
\hline F5 & 25 & Starch 1500 & 27.8 & 300 & 100 & 10 \\
\hline F6 & 35 & Starch 1500 & 27.8 & 150 & 200 & 13 \\
\hline F7 & 25 & Avicel PH 102 & 27.8 & 150 & 100 & 10 \\
\hline F8 & 35 & Avicel PH 102 & 27.8 & 300 & 200 & 13 \\
\hline
\end{tabular}

${ }^{\mathrm{a}}$ Starch 1500 - partially pregelatinized maize starch; Avicel PH 102 - microcrystalline cellulose

properties of tablets with different dimensions. Tensile strength was calculated according to the following equation:

$$
\sigma_{\mathrm{t}}=\frac{2 F}{\pi d h}
$$

where $F$ is the crushing force, $d$ is the tablet diameter and $h$ is the tablet thickness.

\section{Tablets preparation}

Powder mixtures for compression were prepared by using Turbula ${ }^{\circledR}$ shaker-mixer (Glen Mills Inc., Clifton, NJ, USA). Tablets were compressed with direct compression method by using of Presster ${ }^{\mathrm{TM}}$ single station compacting simulator (Metropolitan Computing Corporation, East Hanover, NJ, USA). Simulation of the rotary tablet press Korsch $\mathrm{PH} 336$ was used, with simulated die table speed of $30 \mathrm{rpm}$ which conforms to 65000 tablets per hour and dwell time of 20 ms. Tablets were prepared using punches with diameters of 7,10 and 13 $\mathrm{mm}$, while tablet masses were 180, 360 and $720 \mathrm{mg}$, respectively, according to the experimental design. Compression pressure was calculated from the measured compaction force per cross-sectional area of tablets. Tablets were compressed on different compaction pressures in the range of 100-500 MPa with simulation of the compaction profile of the Korch PH336 rotary tablet press. Tensile strength was calculated from measured hardness and tablet dimensions. Influence of the selected input variables on the tablet tensile strength was analyzed.

\section{Drug release testing}

Drug release test was performed using rotating basket apparatus (Erweka, Hausemmann, Germany) during $4 \mathrm{~h}$ (rotational speed $75 \mathrm{rpm}$, medium volume $600 \mathrm{ml}$ ). Samples were taken after predefined time intervals: $30,120,180,240,360$ and $480 \mathrm{~min}$ and the amount of dissolved tramadol $\mathrm{HCl}$ was determined spectrophotometrically at $\lambda=271 \mathrm{~nm}$. The data collected up to $240 \mathrm{~min}$ were selected for modeling of drug release. During the drug release testing, $\mathrm{pH}$ value of the medium was changed by adding buffer solutions as follows: in the first $30 \mathrm{~min}, \mathrm{pH} \mathrm{1.2;} \mathrm{from} \mathrm{30-120} \mathrm{min,}$ $\mathrm{pH}$ 2.3; from 120-180 min, $\mathrm{pH}$ 6.8; from 180-240 min, $\mathrm{pH}$ 7.2. Artificial gastric juice $\mathrm{pH} 1.2$ was used as well as two buffer solutions for changing $\mathrm{pH}$ value during dissolution test:

Buffer 1: $\mathrm{K}_{2} \mathrm{HPO}_{4}, 63 \mathrm{~g} / 100 \mathrm{ml}(6 \mathrm{ml}$ at $31 \mathrm{~min})$.

Buffer 2: $\mathrm{NaOH} 15 \mathrm{~g} / 100 \mathrm{ml}(6 \mathrm{ml}$ at $121 \mathrm{~min}$ and 3 $\mathrm{ml}$ at $181 \mathrm{~min})$.

\section{Mechanical characterization of tablets}

Tablet hardness was measured using the $8 \mathrm{M}$ tablet hardness tester (Dr. Schleuniger Pharmatron, Thun, Switzerland) and tablet dimensions were measured with digital caliper. Tensile strength was calculated from dimensions of tablets and measured hardness, according to the Eq. (1).

\section{RESULTS AND DISCUSSION}

\section{Evaluation of drug release from PEO matrices}

Tramadol $\mathrm{HCl}$ release profiles from PEO matrices (formulations F1-F8) are presented in Figure 1.

Based on assumption that in hydrophilic matrices with high viscosity polymers and high water-soluble drug diffusion release mechanism is dominating in respect to erosion, drug release process follows Higuchi's model. There is linear relationship between drug release and square-root-of-time (Figure 2) in the certain time intervals and it is related to geometrical characteristics of matrix tablets. Calculated determination coefficient values $\left(R^{2}\right)$ for all formulations were above 0.96, indicating good fitting to Higuchi model.

Percentages of tramadol $\mathrm{HCl}$ released after 30 and $240 \mathrm{~min}$ were selected as indicator of polymer ability to prevent premature drug release and enable sustained release of drug. Furthermore, both time points are within the interval in which drug release follows Higuchi's model. Normalized values of drug released percentage were used in order to eliminate influence 


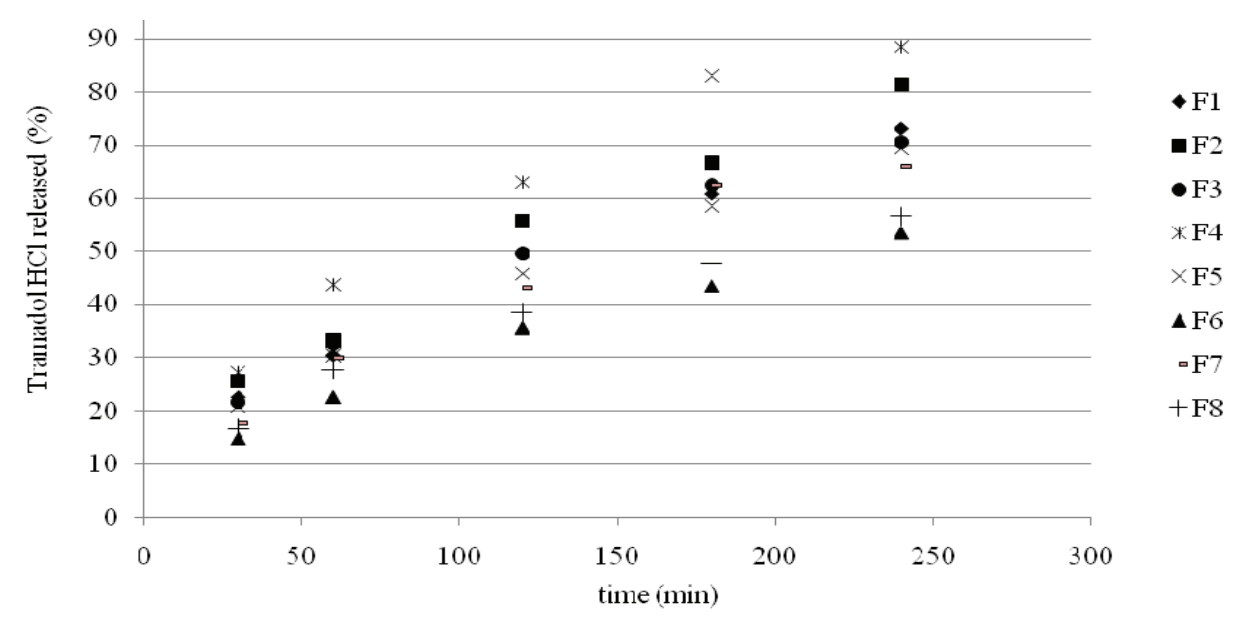

Figure 1. Tramadol HCl release from PEO matrix tablets (formulation F1-F8).

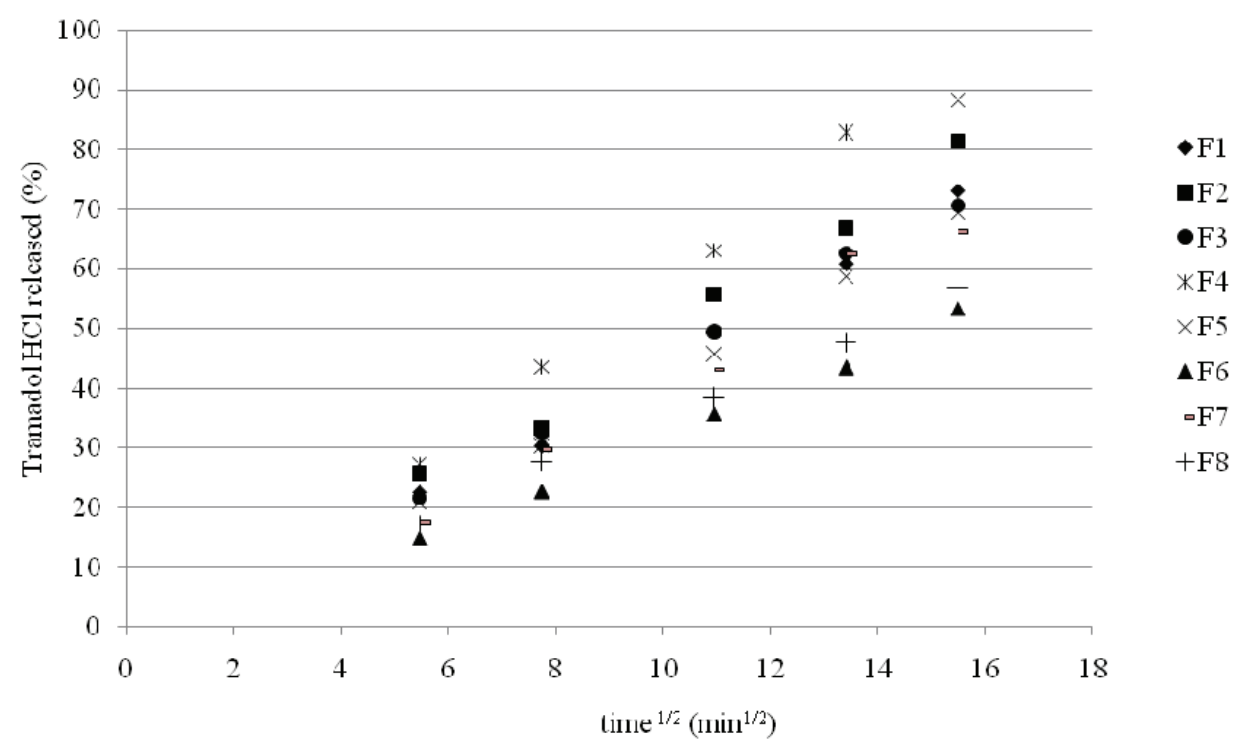

Figure 2. Tramadol $\mathrm{HCl}$ released from formulation F1-F8 per square root of time.

of geometrical characteristics on drug release rate. Normalization was performed by dividing percentage of drug released with surface area per volume ratio $(S A / \mathrm{Vol}$ ) of matrix tablets (Table 2 ).

The influence of selected formulation and process parameters (proportion of PEO polymer, type of insol- uble filler, proportion of tramadol $\mathrm{HCl}$, amount of drug in tablet, tablet diameter and compression pressure) on normalized percentage of drug released at 30 and 240 min was analyzed and presented on Figure 3. Proportion of drug in tablet exhibits statistically significant effect on drug release after $30 \mathrm{~min}(p<0.05)$. With Inc-

Table 2. Normalized values of Tramadol $\mathrm{HCl}$ released after 30 and $240 \mathrm{~min}$

\begin{tabular}{lccccc}
\hline Formulation & $\begin{array}{c}\text { Drug released after } \\
\text { 30 min, \% }\end{array}$ & $\begin{array}{c}\text { Drug released after } \\
240 \mathrm{~min} \%\end{array}$ & $S A /$ Vol & $\begin{array}{c}\text { Normalized values of drug } \\
\text { released after 30 min, \% }\end{array}$ & $\begin{array}{c}\text { Normalized values of drug } \\
\text { released after 240 min, \% }\end{array}$ \\
\hline F1 & 22.6 & 73.0 & 0.893 & 25.3 & 81.8 \\
F2 & 25.7 & 81.3 & 1.047 & 24.5 & 77.6 \\
F3 & 21.5 & 70.6 & 0.890 & 24.2 & 79.3 \\
F4 & 27.3 & 88.3 & 1.057 & 25.8 & 83.6 \\
F5 & 21.0 & 69.3 & 0.904 & 23.2 & 76.7 \\
F6 & 14.9 & 53.3 & 0.716 & 20.9 & 74.5 \\
F7 & 17.6 & 66.1 & 0.916 & 19.3 & 72.2 \\
F8 & 16.8 & 56.7 & 0.749 & 22.4 & 75.8 \\
\hline
\end{tabular}


reasing proportion of drug in tablet, drug release increased.

Influence of other formulation and process variables in selected range have no statistical significant influence on tramadol $\mathrm{HCl}$ release rate. For the drug release at later time point, $240 \mathrm{~min}$, proportion of tramadol $\mathrm{HCl}$ in the formulation has statistical significant influence on drug release, too.

\section{Mechanical characterization of matrices with polyethylene oxide}

Full factorial design was performed in order to evaluate influence of input variables (proportion of poly- mer, type of filler and proportion of tramadol $\mathrm{HCl}$ per tablet) on mechanical characteristics of matrix tablets. Due to different dimensions of tablets the tensile strength was used for evaluation of mechanical characteristics of matrix tablets.

Profiles of tensile strength versus compaction pressure are presented in the Figure 4.

Compression of tablet mixture was performed with compression force up to $40 \mathrm{kN}$, since the punch face diameter of $13 \mathrm{~mm}$ and compression pressure of about $300 \mathrm{MPa}$ compression force is near to maximum possible compression force which could be performed on compaction simulator. Tensile strengths of matrix tab-

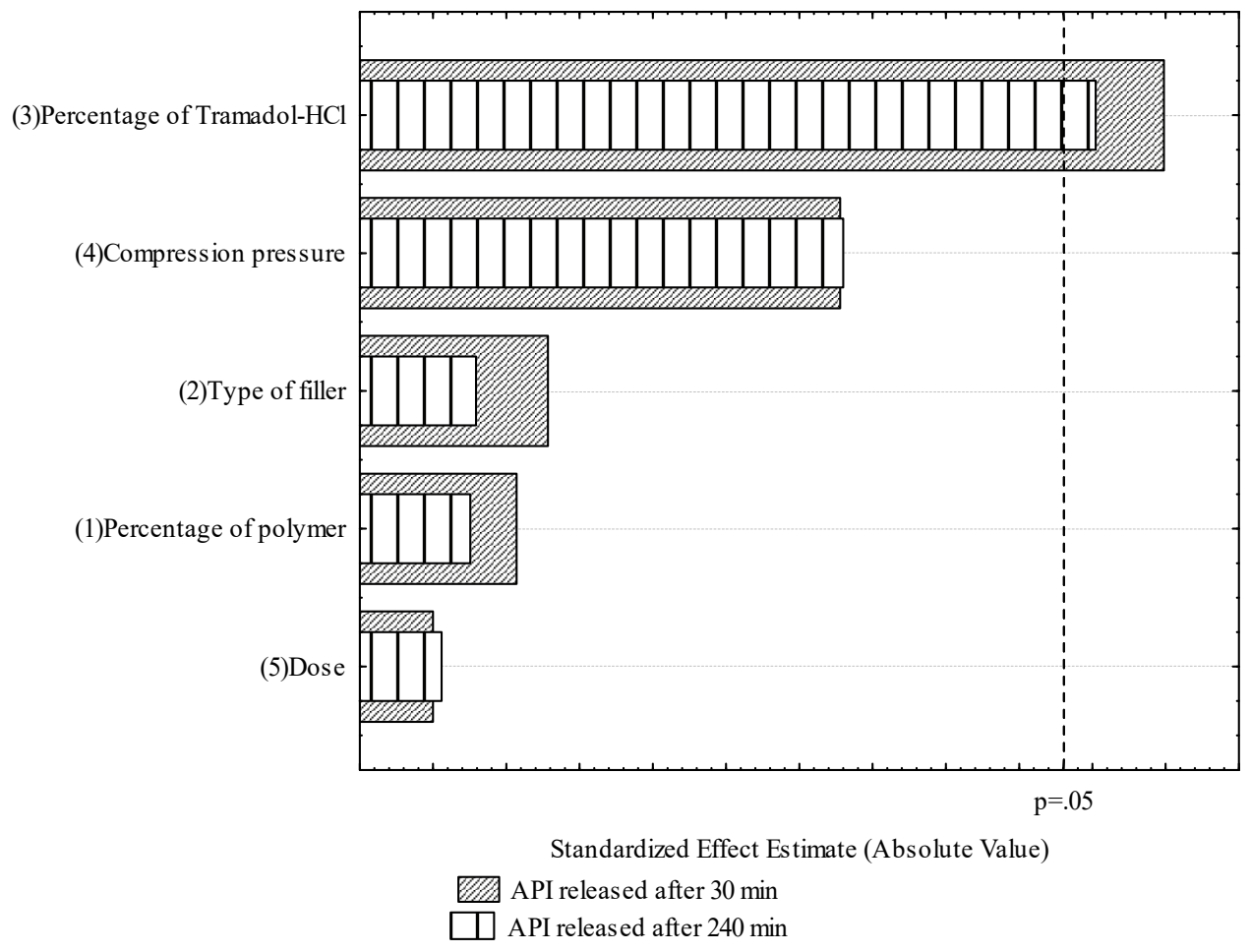

Figure 3. Pareto chart of formulation and process parameters effects on drug released at 30 and 240 min from PEO matrix tablets.

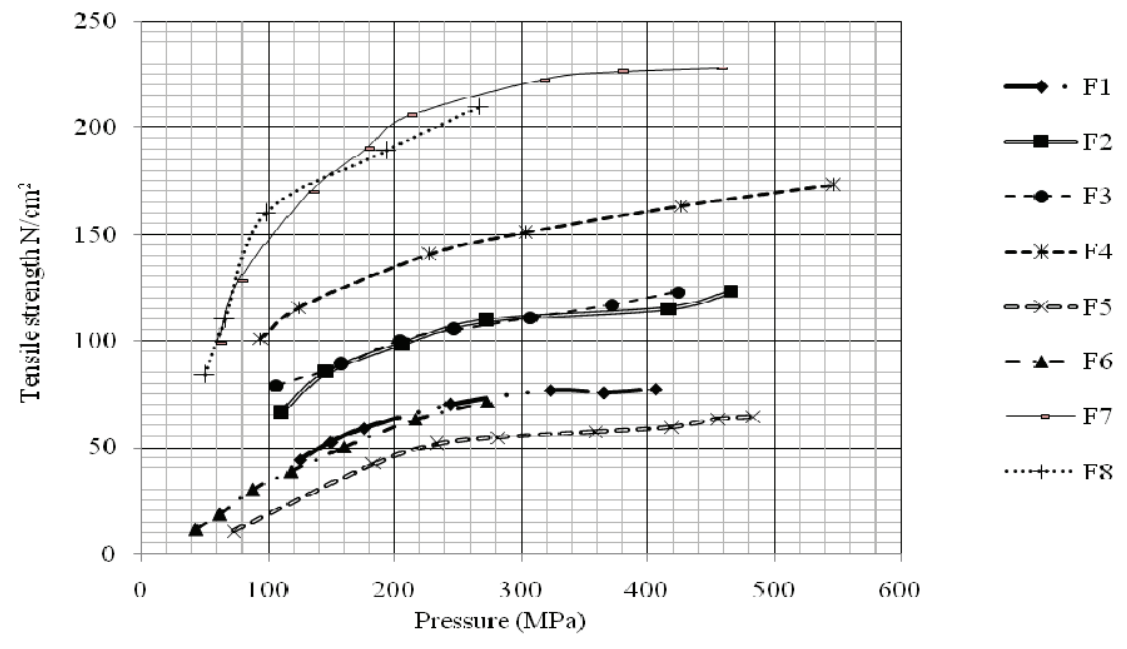

Figure 4. Profiles of tensile strength versus compaction pressure for powder mixtures with PEO WSR coagulant. 
lets on compaction pressures of 120 and $250 \mathrm{MPa}$ were analyzed and compared as output variables (Table 3 ).

Those values of tensile strength were extracted from trend lines of tabletability profiles (Figure 4). Value for compaction pressure of $120 \mathrm{MPa}$ corresponds to values of tensile strength in ascending part of the tabletability profiles diagrams in all trials, while compression pressure of $250 \mathrm{MPa}$ is in the part where the profile reaches plateau. The higher values of tensile strength were obtained when Avicel PH 102 was used as filler comparing to the Starch 1500 . Increase of tramadol $\mathrm{HCl}$ in tablet mixture negatively influences on tensile strength, while increase of PEO polymer in tablet mixture has positive impact on tensile strength.
Pareto diagram of the influence of input variables on tensile strength (for compression pressure of approximately 120 and $250 \mathrm{MPa}$ respectively) is presented in Figure 5.

For PEO matrix tablets almost all input variables exhibit statistically significant effect on tablet tensile strength, with the largest influence of filler type. Mechanical properties of the matrix tablets with highly compressible MCC as filler are significantly better comparing to Starch 1500.

Influence of proportions of polymer, filler and drug (comprising $100 \%$ of tablet) on tensile strength is presented in Figure 6a and b for Avicel PH 102 and Starch 1500 , respectively.

Table 3. Tensile strengths of PEO matrix tablets

\begin{tabular}{|c|c|c|c|c|c|}
\hline Formulation & $\begin{array}{c}\text { Proportion of PEO } \\
\text { polymer, } \%\end{array}$ & Filler type $^{a}$ & $\begin{array}{l}\text { Proportion of tramadol } \\
\qquad \mathrm{HCl}, \%\end{array}$ & $\begin{array}{l}\text { Tensile strength } \\
120 \mathrm{MPa}, \mathrm{N} / \mathrm{cm}^{2}\end{array}$ & $\begin{array}{l}\text { Tensile strength } \\
250 \mathrm{MPa}, \mathrm{N} / \mathrm{cm}^{2}\end{array}$ \\
\hline F1 & 25 & Starch 1500 & 55.6 & 44 & 71 \\
\hline F2 & 35 & Starch 1500 & 55.6 & 71 & 107 \\
\hline F3 & 25 & Avicel PH 102 & 55.6 & 82 & 105 \\
\hline $\mathrm{F} 4$ & 35 & Avicel PH 102 & 55.6 & 115 & 145 \\
\hline F5 & 25 & Starch 1500 & 27.8 & 25 & 53 \\
\hline F6 & 35 & Starch 1500 & 27.8 & 30 & 68 \\
\hline F7 & 25 & Avicel PH 102 & 27.8 & 160 & 212 \\
\hline F8 & 35 & Avicel PH 102 & 27.8 & 170 & 205 \\
\hline
\end{tabular}

${ }^{\mathrm{a}}$ Starch 1500 - partially pregelatinized maize starch; Avicel PH 102 - microcrystalline cellulose

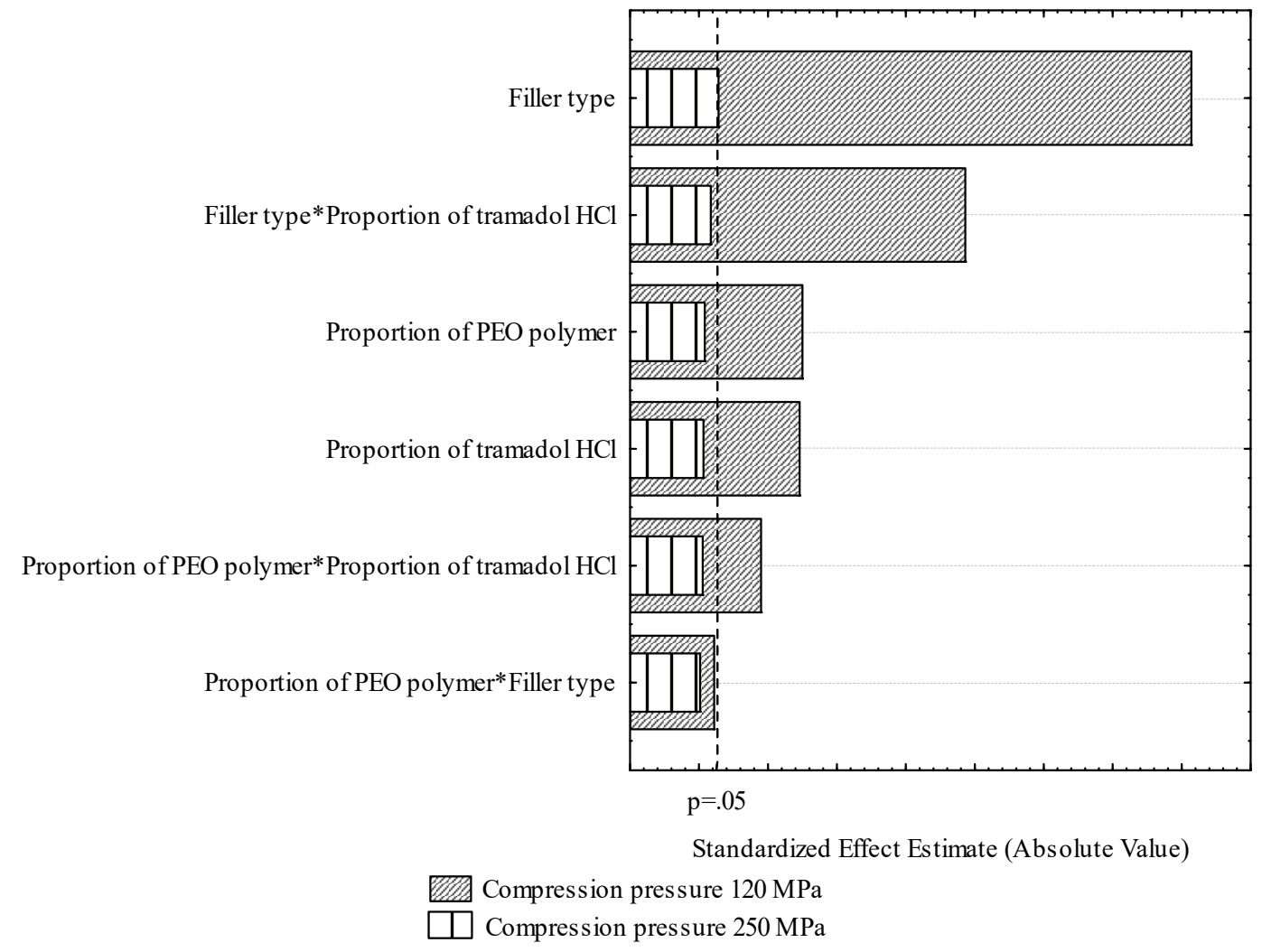

Figure 5. Pareto chart of selected variables effects on tensile strength for PEO matrices for compression pressure of 120 and $250 \mathrm{MPa}$. 


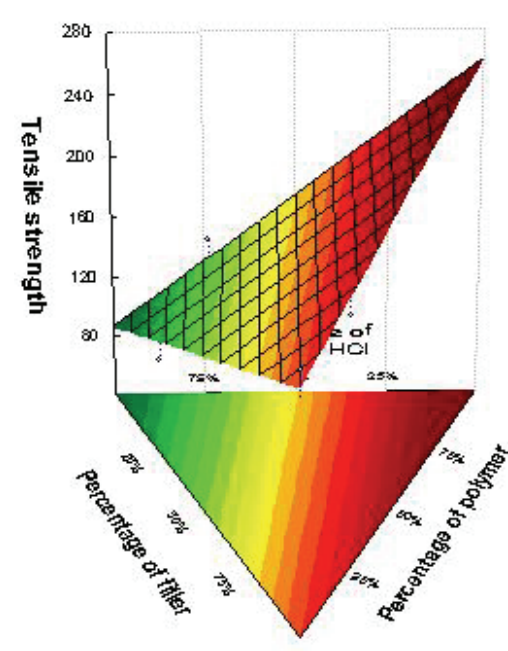

(a)
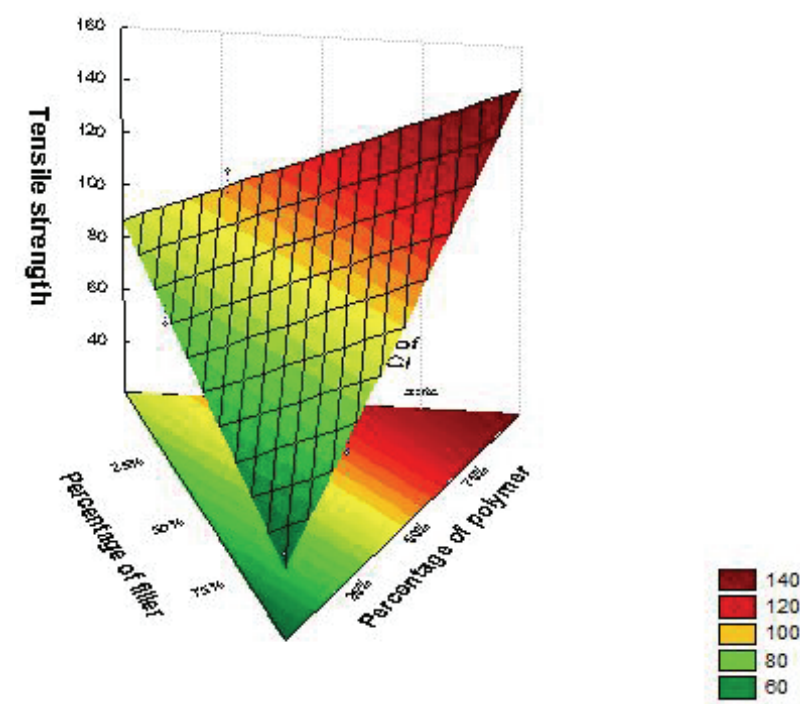

(b) are significantly better with microcrystalline cellulose compared to partially pregelatinized starch. The highest tensile strength was obtained with Avicel PH 102 as filler and with higher percentage of polymer. Obtained results present preliminary evaluation of investigated variables on tablet quality attributes. Since all results were obtained from experiments where variables were varied on two levels, additional experimental work is needed in the future in order to establish mathematical model which will define influence of investigated variables on drug release and tablet mechanical properties.

These findings could be useful in optimization of PEO sustained release matrix tablets with tramadol $\mathrm{HCl}$, as high dose, highly soluble model drug.

\section{Acknowledgements}

This work was done under the project No. TR 34007, supported by the Ministry of Education, Science and Technological Development, Republic of Serbia.

\section{REFERENCES}

[1] S.B. Tiwari, A.R. Rajabi-Siahboomi, Modulation of Drug Release From Hydrophilic Matrices, Pharm. Tech. Europe 20 (2008) 24-32.

[2] C. Wilson, P. Crowley P, eds, Controlled Release in Oral Drug Delivery, Springer, New York, 2011.

[3] S.U. Choi, J. Lee, Y.W. Choi, Development of a directly compressible poly (ethylene oxide) matrix for the sustained-release of dihydrocodeine bitartrate, Drug. Dev. Ind. Pharm. 29 (2003) 1045-1052.

[4] H. Li, R. J. Hardy, X. Gu, Effect of drug solubility on polymer hydration and drug dissolution from polyethylene oxide (PEO) matrix tablets, AAPS Pharm. Sci. Tech. 9 (2008) 437-443.

[5] N. Wu, L. S. Wang, D. Cherng-Wen Tan, S. M. Moochhala, Y. Yang, Mathematical modeling and in vitro study of controlled drug release via a highly swellable and dissoluble polymer matrix: polyethylene oxide with high molecular weights, J. Control. Release 102 (2005) 569$-581$.

[6] C. J. Kim, Drug release from compressed hydrophilic POLYOX-WSR tablets, J. Pharm. Sci. 84 (1995) 303-306.

[7] A. Moroni, I. Ghebre-Sellassie, Application of poly(oxyethylene) homopolymers in sustained release solid formulations, Drug. Dev. Ind. Pharm. 21 (1995) 1411-1428.

[8] J. Petrović, J. Jocković, S. Ibrić, Z. Đurić, Modelling of diclofenac sodium diffusion from swellable and watersoluble polyethylene oxide matrices, J. Pharm. Pharmacol. 61 (2009) 1449-1456.

[9] P. Colombo, R. Bettini, P. Santi, A. DeAscentiis, N. A. Peppas, Analysis of the Swelling and Release Mechanisms from Drug Delivery Systems with Emphasis on Drug Solubility and Water Transpor, J. Control. Release 39 (1996) 231-237.

[10] R. Bettini, P. L. Catellani, P. Santi, G. Massimo, N. A. Peppas, P. Colombo, Translocation of drug particles in HPMC matrix gel layer: effect of drug solubility and 
influence on release rate, J. Control. Release 70 (2001) 383-391.

[11] J. Siepmann, H. Kranz, N. A. Peppas, R. Bodmeier, Calculation of the required size and shape of hydroxypropyl methylcellulose matrices to achieve desired drug release profiles, Int. J. Pharm. 201 (2000) 151-164.

[12] T.D. Reynolds, S.H. Gehrke, A.S. Hussain, L.S. Shenouda, Polymer Erosion and Drug Release Characterization of Hydroxypropyl Methylcellulose Matrices, J. Pharm. Sci. 87 (1998) 1115-1123.

[13] M. K. Divi, T. Dürig, W. Harcum, Drug Release from Hydroxypropylcellulose Sustained Release Matrix Tablets: Implications of Tablet Surface Area/Volume Ratio, MW and Drug Solubility, Aqualon Pharmaceutical Technology Report PTR-068, 2008.
[14] L. Yang, K. Venkatesh, R. Fassihi, Characterization of compressibility and compactibility of poly(ethylene oxide) polymers for modified release application by compaction simulator, J. Pham. Sci. 85 (1996) 1085$-1090$.

[15] The Influence of In Vitro Dissolution Method on the Release of a Highly Water Soluble Drug from Polyethylene Oxide and Hypromellose Hydrophilic Extended Release Matrices, available from http:// //www.colorcon.com

[16] S. Patel, A. M. Kaushal, A. K. Bansal, Compression physics in the formulation development of tablets, Crit. Rev. Ther. Drug. Carrier Sys. 23 (2006) 1-65.

\section{IZVOD}

\section{ISPITIVANJE UTICAJA FAKTORA FORMULACIJE I PROCESA NA OSLOBAĐANJE TRAMADOL HIDROHLORIDA I MEHANIČKE KARAKTERISTIKE MATRIKS TABLETA SA PRODUŽENIM OSLOBAĐANJEM}

Nenad D. Nikolić ${ }^{1}$, Đorđe P. Medarević ${ }^{2}$, Svetlana R. Ibrić ${ }^{2}$, Zorica R. Đurić2

${ }^{1}$ Hemofarm a.d., Beogradski drum b.b., Vršac, Srbija

${ }^{2}$ Katedra za farmaceutsku tehnologiju i kozmetologiju, Farmaceutski fakultet - Univerzitet u Beogradu, Srbija

(Naučni rad)

$U$ radu je ispitivan uticaj formulacijskih i procesnih promenljivih na brzinu oslobađanja i mehaničke karakteristike matriks tableta izrađenih sa polietilen oksidom velike molekulske mase (PEO WSR koagulant), kao matriks formirajućim materijalom i visoko rastvoljivom lekovitom supstancom prisutnoj u velikoj dozi, tramadol hidrohloridom. Kao formulacijske promenljive varirane su: udeo polietilen oksidnog polimera (25 ili 35\%), vrsta nerastvornog sredstva za dopunjavanje (mikrokristalna celuloza i parcijalno pregelirani skrob), udeo tramadol hidrohlorida (27,8 i 55,6\%), količina leka u tableti (100 ili 200 mg). Pritisak kompresije je variran kao procesna promenljiva. Procenat tramadol hidrohlorida rastvoren nakon 30 i 240 min ispitivanja je izabran kao zavisno promenljiva za ispitivanje oslobađanja lekovite supstance, dok je zatezna čvrstoća izabrana kao zavisno promenljiva koja je indikator mehaničkih karakteristika tableta. Izvedena su dva seta eksperimenata, koji odgovaraju $2^{5-2}$, odnosno $2^{3}$ eksperimentalnom dizajnu. Tablete su izrađene na simulatoru kompakcije Prester. Simuliran je rad rotacione tablet prese Korch PH336, sa brzinom rotacije $30 \mathrm{rpm}$, što odgovara kapacitetu od 65000 tableta na sat. Ispitivanje uticaja faktora formulacije i procesa na oslobađanje tramadol hidrohlorida pokazalo je da se iz svih formulacija tramadol hidrohlorid oslobađa usporeno, linearnom kinetikom. Najveći uticaj na procenat oslobođenog leka imao je udeo leka u tableti. Sa povećanjem udela leka u tableti, povećavao se i procenat oslobođenog leka u navedenim vremenskih intervalima. Ostali isptivani faktori nisu imali značajan uticaj na brzinu oslobađanja. Ispitvanje mehaničkih karakteristika tableta pokazalo je da na zateznu čvrstoću izrađenih tableta najveći uticaj ima vrsta sredstva za dopunjavanje. Najveće vrednosti zatezne čvrstoće su dobijene u slučaju kada je mikrokristalna celuloza korišćena kao sredstvo za dopunjavanje, kao i kada je procenat polimera u tableti bio na višem nivou. Analiza dobijenih rezultata omogućava pravilan izbor vrste i koncentracije pomoćnih materija u formulaciji matriks tableta sa produženim oslobađanjem izrađenih sa polietilen oksidnim polimerom i visoko rastvorljivom lekovitom supstancom prisutnoj u velikoj dozi.
Ključne reči: Tramadol $\mathrm{HCl} \bullet$ Matriks tablete • PEO WSR koagulant • Oslobađanje lekovite supstance • Mehaničke karakteristike tableta 